\title{
Status of the Gannet Morus bassanus in the Black Sea region (E Bulgaria)
}

\section{Status strmoglavca Morus bassanus v Črnomorski regiji (V Bolgarija)}

\author{
Zlatozar Boev \\ National Museum of Natural History, Bulgarian Academy of Sciences, 1, blv. Tsar Osvoboditel, BG-1000 Sofia, \\ Bulgaria, e-mail: boev@nmnh.bas.bg
}

The Gannet Morus bassanus is a rare vagrant species in the Black Sea region (E Bulgaria). There are altogether 9 records of Gannet in Bulgaria over the last 100 years, all on the Black Sea coast. This paper describes the three most recent records. On 29-31 July 20086 individuals were observed in the vicinity of St. Constantine and Elena Resort (12 km north of the town of Varna, Varna Region, NE Bulgaria). Gannets were fishing by numerous (typical) dives, accompanied by a flock of Cormorants Phalacrocorax carbo and Yellow-legged Gulls Larus michahellis. A review of all the species' records in Bulgaria, as well as the subfossil records in the Black Sea region is given.

Key words: Gannet, Morus bassanus, Bulgaria, Black Sea

Ključne besede: strmoglavec, Morus bassanus, Bolgarija, Črno morje

\section{Introduction}

The present breeding distribution of Gannet Morus bassanus can be described as North Atlantic. The range outside the breeding season also includes the whole Mediterranean, except the Sea of Marmara (Carboneras 1992). The species has been described as an accidental visitor in the former Yugoslavia, Greece, Turkey, Lebanon, Syria and Cyprus (Cramp \& Simmons 1977), some of these countries being neighbours of Bulgaria. WANLESS (1997) states that the Gannet's distribution away from the colonies is relatively well known and that the breeding birds are partial migrants dispersing south to the Bay of Biscay or into the Mediterranean. Its status in the Mediterranean has been studied much more exhaustively than that in the Black Sea (Paterson 1993). In this work I present existing data on Gannet in the Bulgarian Black sea region, together with some recent observations.

\section{Literature data}

According to Michev (1990), the only two Bulgarian records of the species are from the Black Sea coast. The first, in 1912, is that of VARBANOV (I9I2) in the vicinity of the town of Burgas, and the second (1 immature bird), by K. Warnke (published by KöNigstedt \& RobeL 1978) on 10 Aug 1969 in the vicinity of Slanchev Bryag resort (32 km north of Burgas). Boev (1962) specified that record of VARBANOV (I9I2) rests on proofs that cannot be accepted, but NankinOv \& Todorov (2006) comment that this specimen was actually observed during the winter in 1912 in the suburbs of Burgas. The latter authors report the record of an immature individual Gannet on 9 Jun 2005, flying over the sea in the vicinity of Shabla Lake, accompanied by a mixed flock of Yellow-legged Gulls Larus michahellis and Mediterranean Gulls Larus melanocephalus. In addition, two records are listed in the database of the Bulgarian National Rarities Committee (BUNARCO): (1) on 28 Sep 1985 in the Atanasovsko Lake Nature Reserve near Burgas (SCHIMKart 1992, cited in NANKINOV \& Todorov 2006), and (2) on 8 Aug 1995 in the Uzungeren Protected Locality (Mandra Lake) of Kiril Bedev. Nankinov (1992) asserted the status of Gannet in Bulgaria as accidental visitor. Kostadinova \& Gramatikov (2007) included Gannet in the list of bird species occurring in Bulgaria. Recently Gannet was listed as a vagrant in Bulgaria (BIRDLIFE INTERNATIONAL 2008). In addition, Christophers (2007) observed, 


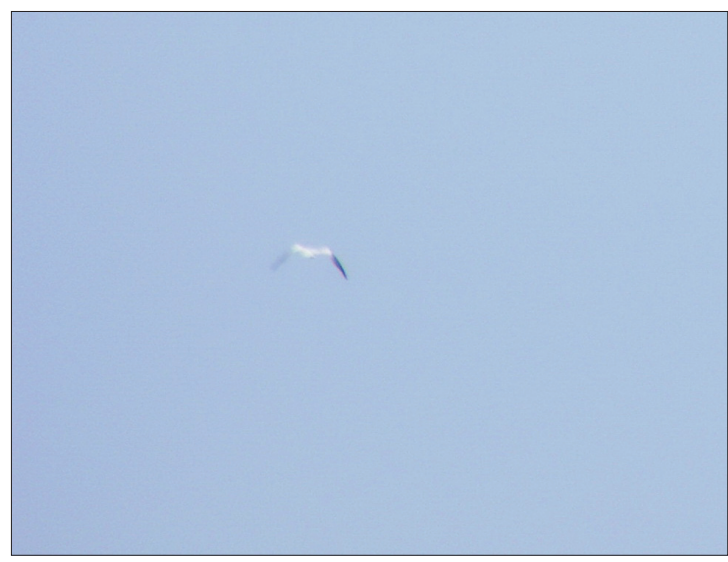

Figure 1: One of the Gannets Morus bassanus observed on $30 \mathrm{Jul} 2008,12 \mathrm{~km}$ north of town of Varna (NE Bulgaria). Photo: Z. Boev

Slika 1: Eden izmed strmoglavcev Morus bassanus, opaženih 30.7.2008 $12 \mathrm{~km}$ severno od mesta Varna (SV Bolgarija). Foto: Z. Boev

on 18 Jun 2007, an adult Gannet flying from north to south along the edge of the sea, above the beach of Shabla (Dobrich Region, NE Bulgaria). Thus, the Gannet is a very rarely observed species in the 120 -year long history of Bulgarian ornithology.

\section{Recent observations}

On 29-31 Jul 2008 we observed up to 6 Gannets in the region of the St. Constantine and Elena Resort $(12 \mathrm{~km}$ north of town of Varna, Varna Region, NE Bulgaria). Each day the weather was sunny, calm and warm with daily temperatures up to $28^{\circ} \mathrm{C}$. The observations lasted from 20 seconds up to 2-3 minutes.

On 29 Jul 2008 at about $11.00 \mathrm{~h}$ an adult bird was seen in flight in a north-easterly direction over the sea at approx. $200 \mathrm{~m}$ from the shore in the region of the Hotel Complex Slanchev Den (in the northern part of the St. Constantine and Elena Resort). It flew at approx. $30 \mathrm{~m}$ above the sea surface with slow wing beats. The wings were sharp, very long and with bright black tips. All other parts were white. The rear profile had the characteristic bends in the middle of the wings. Compared to the otherwise common Yellowlegged Gull Larus michahellis and to 3 Cormorants Phalacrocorax carbo, flying at that time in the region, the observed bird appeared very large.

On 30 Jul 2008 between 11.30 and 12.00, 5-6 adult birds were observed in flight over the sea from a small touristic motor-boat about 350-500 $\mathrm{m}$ from the shore (Figure 1). All birds were fishing and constantly made the specific dives into the water from 10-12 $\mathrm{m}$ height. The Gannets were fishing, together with a flock of Cormorants, and landing on the sea surface.

On 31 Jul 2008 at about 11.45 we saw 2 adult Gannets fishing about $350 \mathrm{~m}$ from the coast. They dived quite impressively, and were accompanied by a group of Yellow-legged Gulls, later staying on the water surface. The Yellow-legged Gulls rested on the sea surface beside the Gannets, apparently unaffected by them. At about 12.002 Gannets were spotted in the air, again at about $300-400 \mathrm{~m}$ from the shore. One of them appeared to have dark plumage (juvenile?), but we could not see the bird well enough. Christophers (2007) writes that the Gannet's flight is level and strong, with steady shallow wingbeats interspersed with short glides. Precisely the same can be said for all the birds observed in the region of the St. Constantine and Elena Resort. Some terns (Sternidae) also dive in the sea, and most of them also have white body plumage and black wing tips, but their size is very much smaller, while the wing beats are much more frequent. The specific diagnostic field features of Gannet and its particular fishing behaviour exclude any false identification. These records were accepted by the National Rarities Committee (BUNARCO).

\section{Discussion}

The former distribution (in Antiquity and later) of Gannet is well documented by a series of bone remains in the Northern part of the Black Sea. BurchaKAbramovic \& TSalkin (I97I \& 1974) reported on 3 subfossil bones of 2 adult individuals of Gannet, found in 1969 in a Skithian settlement of Crimea (the Ukraine), dated 2000 B.C. Antipina (I98I) states that the remains of Gannet are found regularly in the ancient archaeological sites of the North-West Crimea (cited in Panteleyev 200I). In addition, in the Eastern part of Crimea, he reported on 6 bones ( 4 individuals) from Nymphaea $\left(4^{\text {th }}-2^{\text {nd }}\right.$ century B.C. and $1^{\text {st }}-2^{\text {nd }}$ century A.D.) and 1 bone (1 individual) each from Pantikapea ( $4^{\text {th }}$ century B.C. $-2^{\text {nd }}$ century A.D.) and Mirmekia (probably $14^{\text {th }}-15^{\text {th }}$ century A.D.). Thus, the Ukrainian records prove the Holocene distribution of Gannet in the Black Sea.

Present records (numbered $7^{\text {th }}$ to $9^{\text {th }}$ ) of Gannet in Bulgaria possibly confirm its actual recent dispersion eastwards, encompassing the Black Sea region, but they could also be simply the result of the more elaborated avifaunal explorations in the recent years. The seasonal distribution of the records covers 3 seasons: winter (1 record - Jan-Feb 1912); spring (2 records - 9 Jun 1969; 18 June 2007); summer 


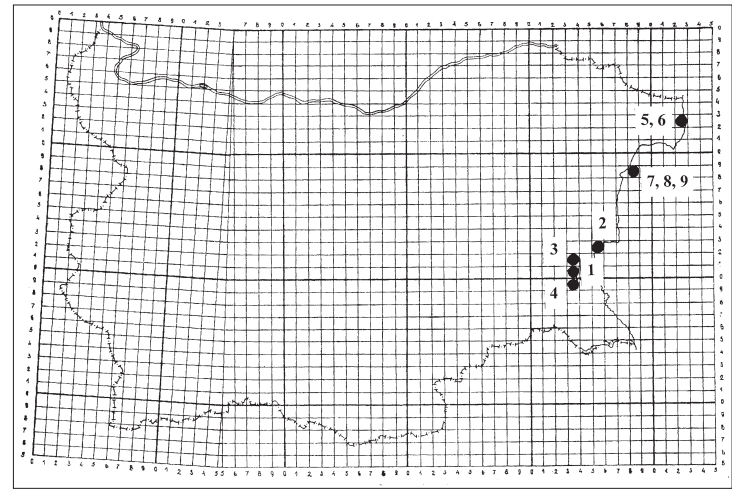

Figure 2: The occurrence of Gannet Morus bassanus in Bulgaria: 1 - Burgas (1912); 2 - Slanchev Bryag (1969); 3 - Atanasovsko Lake (1985); 4 - Uzungeren (Mandra Lake) (1995); 5, 6 - Shabla Lake (2006, 2007); 7, 8, 9 - St. Constantine and Elena (2008)

Slika 2: Pojavljanje strmoglavca Morus bassanus v Bolgariji: 1 - Burgas (1912); 2 - Slanchev Bryag (1969); 3 Atanasovsko jezero (1985); 4 - Uzungeren (jezero Mandra) (1995); 5, 6 - jezero Shabla (2006, 2007); 7, 8, 9 - St. Constantine in Elena (2008)

(5 records - 29-31 Jul 2008; 8 Aug 1995; 10 Aug 1969); autumn (1 record - 28 Sep 1985). Neglecting the dubious record in the winter of 1912, all the remaining observations fall in the summer period, i.e. 9 Jun - 28 Sep. Only 2 of the 15 observed individuals of Gannet were immature. All the other individuals were adults with mature plumage. All the birds were observed in flight over the sea and none landed on the coast. All records are concentrated along the Bulgarian Black Sea coast (Figure 2). Obviously, the records of the Gannet along the western Black Sea (Bulgarian) coast in the last decade have become more frequent, but it is still premature to state that a change of the species' status has occurred.

Acknowledgments: The author thanks Dr Bozhidar Ivanov (Institute of Zoology, BAS) for providing data and for critical remarks on an earlier version of the manuscript.

\section{Povzetek}

Strmoglavec Morus bassanus je naključni gost v Črnomorski regiji (V Bolgarija). Skupno je znanih 9 zapisov za strmoglavca v Bolgariji, vsi v tej regiji. V članku so predstavljeni trije najnovejši zapisi. V dneh med 29. in 31.7.2008 je bilo opazovanih največ 6 osebkov na območju naselij St. Constantine in Elena (12 km severno od Varne, SV Bolgarija). Strmoglavci so lovili ribe, se večkrat značilno potopili, skupaj z njimi pa je bila tudi jata kormoranov Phalacrocorax carbo in rumenonogih galebov Larus cachinnans. Avtor podaja pregled vseh zapisov strmoglavca v Bolgariji in tudi pregled subfosilnih ostankov vrste v Črnomorski regiji.

\section{References}

Antipina, E. (198I): Impoverishment of the avifauna of the North-Western Crimea in the historic times and the economic activity. - Ecology and conservation of birds. Proceedings of the $8^{\text {th }}$ All-Union ornithological Conference, Kishinew, 1981. (in Russian; cited in Panteleyev 200I)

BirdLife International (2008): BirdLife Species Factsheet (additional data) LC, Gannet Morus bassanus. [http://www.birdlife.org/datazone/species/index.html? action $=$ SpcHTMDetails asp\&sid $=3652 \& \mathrm{~m}=1]$.

BUNARCO (2008): Bulgarian National Rarities Committee Database. - BSPB, Sofia.

Boev, N. (1962): Northern Gannet - Sula bassana. pp 325 In: Peshev, T. \& Boev, N. (1962): Fauna of Bulgaria. A Brief Guide (of Vertebrate Animals). - Narodna Prosveta Publ. House, Sofia. (in Bulgarian)

Burcak-Abramovic, N. \& Calkin, V. (I97I): K poznaniju ornitofauni juga Ukraini, Krima i Podonia (po arheologicheskim materialam). - Bull. MOIP Otd. Biol. 75: 54-63.

Burcak-Abramovic, N. \& Calkin V. (I974): Zaleti atlanticheskoi Oluchi Sula bassana bassana (L) na Chernoe more. - Soobcht. Pribalt. Kom. po izuch migracii ptic 8: 206-213.

Carboneras, C. (I992): Family Sulidae (Gannets and Boobies). pp. 312-325 In: DEl Hoyo, J., Elliot, A. \& Sargatal, J. (eds.): Handbook of the Birds of the World. Vol. 1. - Lynx Edicions, Barcelona.

Christophers, S. (2007): Observation of an adult Gannet (Morus bassanus) and Pomarine Skua (Stercorarius pomarinus) along the Black Sea coast of Bulgaria.[http:// www.branta-tours.com/lbs.php].

Cramp, S. \& Simmons, K.E.L. (eds.) (i977): Handbook of the Birds of Europe the Middle East and North Africa. The Birds of Western Palearctic, Vol. I. Ostrich to Ducks. - Oxford University Press.

Königstedt, D., \& Robel, D. (I978): Zur Avifauna Bulgariens (Ein Nachtrag). - Beitr. Vögelkd. 24: 276-280.

Kostadinova, I. \& Gramatikov, M. (eds.) (2007): Important Birds Areas in Bulgaria and Natura 2000. Nature Conservation Series, Book 11. - BSPB, Sofia.

Michev, T. (I990): 4. Order Pelecaniformes - Pelecaniform. pp. 79-96 In: Simeonov, S., Michev, T. \& Nankinov, D.: Fauna of Bulgaria, Vol. 20., Aves. - Publ. House of the Bulg. Acad. of Sci., Sofia.

Nankinov, D. (I992): Checklist of bird species and subspecies in Bulgaria. - Avocetta 16: 1-17.

Nankinov, D. \& Todorov, N. (2006): Der Einflug des Basstölpels ins Schwarze Meer. - Ornithologische Mitteilungen 58 (1): 29-33. 
Panteleyev, A. (200I): Occurrences of bones of the Gannet (Sula bassana) in the Crimea of the Antiquity. The Bosphorus phenomenon: the colonization of the region, formation of polises, formation of state. Proceedings of the International scientific conference, Part 2. - The Hermitage Publishing House, Sankt Peterburg. (in Russian)

Paterson, A. (1993): The status of the Gannet (Sula bassana) in the Mediterranean. pp. 161-171 In: Aguilar, J.S., Monbailliu, X. \& Paterson, A. (eds.): Proceedings of the $2^{\text {nd }}$ Medit. Seabird Symposium Status and Conservation of seabirds - Ecogeography and Mediterranean Action Plan, Calvia, 21-26 March 1989. - SEO and MEDMARAVIS.

SchimkAT, J. (1992): Vogelbeobachtungen in Bulgarien. Teil 1: Beobachtungen von seltenen Vogelarten in Bulgarien. - Falke 39: 330-332.

VArbanov, V. (I912): The marsh game in the vicinities of Burgas. - Lovets 5: 50-51. (in Bulgarian)

Wanless, S. (1997): Morus bassanus. pp. 30-31 In: Hagemeijer, W.J.M. \& Blair, M.J. (eds.): The EBCC Atlas of European Breeding Birds. Their Distribution and Abundance. - T \& AD Poyser, London.

Arrived / Prispelo: 5.8.2008

Accepted / Sprejeto: 5.8.2009 